\title{
Pengaruh Model Pembelajaran Jurisprudential Inquiry Terhadap Kemampuan Berargumentasi Peserta Didik
}

\author{
Hana Nahdiana ${ }^{1}$, Tri Harjawati ${ }^{2}$, Jakiatin Nisa ${ }^{3}$ \\ 1,2,3Universitas Islam Negeri Syarif Hidayatullah Jakarta \\ email: jakiatin.nisa@uinjkt.ac.id
}

Naskah diterima: 23 November 2019, direvisi: 16 Desember 2019, disetujui: 28 Desember 2019

\begin{abstract}
This study aims to examine the effect of the application of the Jurisprudential Inquiry learning model to students' ability to argue. The research approach uses a quantitative approach with the Quasi Experiment method with The Pretest-Posttest Control Group Design. The study population was all grade X students in SMA Dua May. The sample was students of class X IPS 1 and X IPS 2, each of which numbered 32, the samples were taken by purposive sampling. The data collected was analyzed using descriptive analysis and inferential statistics using the independent sample t-test. Based on the results of data analysis, there are significant differences in the ability to argue between groups of students who learn to use the Jurisprudential Inquiry Learning Model and groups of students who learn by using the Conventional Learning Model. Where is t-count $>$ t-table (10,639> 1,697). Jurisprudential Inquiry learning model influences $23.14 \%$ in the experimental class on the ability to argue students. Thus the Jurisprudential Inquiry learning model has a positive effect on students' ability to argue.
\end{abstract}

Keywords: Learning Model, Jurisprudential Inquiry, Ability to Argue.

\begin{abstract}
Abstrak
Penelitian ini bertujuan untuk menguji pengaruh penerapan model pembelajaran Jurisprudential Inquiry terhadap kemampuan berargumentasi peserta didik. Pendekatan penelitian menggunakan pendekatan kuantitatif dengan metode Quasi Eksperimen dengan The Pretest-Posttest Control Group Design. Populasi penelitian adalah seluruh peserta didik kelas X di SMA Dua Mei. Sampelnya adalah peserta didik kelas X IPS 1 dan X IPS 2 yang masing-masing berjumlah 32, sampel diambil dengan cara purposive sampling. Data yang dikumpulkan dianalisis dengan menggunakan analisis deskriptif dan statistic inferensial menggunakan uji-t independent sample test. Berdasarkan hasil analisis data, terdapat perbedaan kemampuan berargumentasi yang signifikan antara kelompok peserta didik yang belajar menggunakan Model Pembelajaran Jurisprudential Inquiry dengan kelompok peserta didik yang belajar dengan menggunakan Model Pembelajaran Konvensional. Dimana t-hitung $>$ t-tabel $(10.639>1,697)$. Model pembelajaran Jurisprudential Inquiry berpengaruh sebesar 23,14\% pada kelas eksperimen terhadap kemampuan berargumentasi peserta didik. Dengan demikian maka model pembelaran Jurisprudential Inquiry berpengaruh positif terhadap kemampuan berargumentasi peserta didik.
\end{abstract}

Kata Kunci: Model Pembelajaran, Jurisprudential Inquiry, Kemampuan Berargumentasi. 


\section{PENDAHULUAN}

Fungsi model pembelajaran adalah sebagai pedoman bagi perancang pengajar dan para guru dalam melaksanakan pembelajaran. Seperti yang dikemukakan oleh Joyce, Weil dan Calhount (2011) bahwa setiap model yang akan digunakan dalam pembelajaran menentukan perangkat yang dipakai dalam pembelajaan tersebut.

Model-model pembelajaran menurut Kasmad (2012: 14) terdapat bermacam-macam di antaranya yaitu model pembelajaran kontruktivisme, model pembelajran CTL (Contextual Teaching and Learning), model pembelajaran kooperatif (Cooperative Learning), model pembelajaran berbasis PAIKEM, model pembelajaran berbasis inkuiri, dan lain-lain.

Berdasarkan hasil pengamatan yang telah dilakukan oleh peneliti pada bulan November 2017, Selama proses kegaitan belajar mengajar di SMA Dua Mei Tangerang Selatan masih menggunakan pembelajaran konvensional (ceramah), pembelajaran konvensional atau yang sering disebut dengan teacher oriented dimana guru masih menjadi pusat kegiatan belajar mengajar dan peserta didik belum bisa mencari informasi sendiri masih bergantung pada guru. Hal ini terjadi karena kurangnya pemahaman guru mengenai model-model pembelajaran dan memanfaatkan fasilitas yang tersedia. Minimnya penggunaan model pembelajaran membuat peserta didik menjadi tidak antusias dalam proses pembelajaran. Dengan demikian hal ini menjadikan peserta didik kesulitan dalam memahami mata pelajaran tersebut, sulit menjelaskan kembali, peserta didik sulit untuk menyampaikan hal-hal yang belum dipahaminya yang akan berdampak pada rendahnya kemampuan berargumentasi peserta didik.

Salah satu model pembelajaran yang dapat mengasah kemampuan berargumentasi peserta didik adalah dengan menggunakan model pembelajaran Jurisprudential Inquiry, dimana model pembelajaran yang dipelopori oleh Donal Oliver dan James P. Shaver (dalam Joyce, Weil dan Calhoun, 2011) ini didasarkan atas pemahaman masyarakat di mana setiap orang berbeda pandangan dan prioritas satu sama lain, dan nilai-nilai sosialnya saling berkonfrontasi satu sama lain. Memecahkan masalah kompleks dan kontroversial di dalam konteks aturan sosial yang produktif membutuhkan warga negara yang mampu berbicara satu sama lain dan bernegosiasi tentang keberbedaan tersebut.

Model pembelajaran ini melatih peserta didik untuk peka terhadap permasalahan sosial, mengambil posisi (sikap) terhadap permasalahan tersebut, serta mempertahankan sikap tersebut dengan argumentasi yang relevan dan valid. Model ini juga dapat mengajarkan peserta didik untuk dapat menerima atau menghargai sikap orang lain terhadap suatu masalah yang mungkin bertentangan dengan sikap yang ada pada dirinya, atau sebaliknya ia bahkan menerima dan mengakui kebenaran sikap yang diambil orang lain terhadap suatu isu sosial tertentu. Sebagai contoh, seorang peserta didik menyampaikan argumentasinya mengenai kelemahan BUMN dan BUMD dengan argumentasi yang rasional dan logis.

Semakin berkembangnya zaman yang modern dan terpengaruh oleh globalisasi menuntut setiap warha negara agar senantiasa belajar untuk menghadapi hidupnya dan tidak kaget jika ada gejala-gejala sosial yang ada di lingkungan sekitarnya. Proses perubahan pendidikan yang terus-menerus agar manusia bisa lebih bermakna dan siap menghadapi hidupnya. Salah satu cara untuk menghadapi perkembangan zaman dan perubahan pendidikan secara terus-menerus adalah dengan kemampuan beragumentasi, karena hanya dengan kemampuan argumentasi peserta didik mampu mengambil posisi dan sikap untuk untuk menyeleksi benar dan tidaknya informasi yang didapatnya seiring dengan maraknya globalisasi.

Menurut Hendrikus (1991: 19) menyatakan bahwa orang yang menguasai ilmu retorika dan terampil dalam mempergunakan bahasa, dapat mengalami banyak sukses dalam dihup dan karyanya, antara lain (1) mengalami kemudahan dalam proses berkomunikasi, (2) baginya terbuka kesempatan dan kemungkinan yang lebih luas untuk mendapatkan kerja, (3) lebih mudah mendapat pengakuan dan penghargaan dari orang lain (4) pengertian terhadap orang lain semakin terbina, dan (5) dapat ter- 
bina sikap batin yang positif terhadap sesama dan dunia sekitar, yang dapat memperbesar sukses dalam hidup dan karyanya.

Argumentasi adalah pendapat seseorang yang didasarkan dengan fakta yang mampu untuk mempengaruhi, dengan menggunakan fakta maka ini akan meyakinkan orang lain tentang kebenaran atas pemikirannya dan ditambahkan dengan contoh realita di lingkungan sekitar. Kemampuan beragumentasi sangat penting diajarkan kepada peserta didik agar peserta didik mampu mengatasi permasalahan atau gejala sosial sehingga dapat memecahkan masalah tersebut dalam kehidupan sehariharinya baik dalam lingkungan keluarga, sekolah, maupun masyarakat sekitar.

Dari paparan di atas sangat penting mengembangkan kemampuan peserta didik agar mereka mampu mengatasi permasalahan dan memecahkan masalah sendiri, kemampuan berargumentasi dapat diajarkan melalui model pembelajaran Jurisprudential Inquiry.

Berdasarkan jurnal pendidikan dari Riyanti (2016) yang berjudul Model Pembelajaran Jurisprudential Inquiry Untuk Mengukur Hasil Belajar Peserta didik Sekolah Dasar Pada Pembelajaran PKn menghasilkan Jurisprudential Inquiry berpengaruh terhadap hasil belajar peserta didik, berdasarkan data permasalahan dan alternative pemecahannya dalam 67,5\% menjadi $80 \%$. Sehingga mengalami kenaikan sebesar $12,5 \%$.

Tiyani (2016) memperkuat pendapat Riyanti diatas dengan menyatakan dalam artikel yang berjudul Pemanfaatan Model Jurisprudential Inquiry Untuk Meningkatkan Keterampilan Menulis Cerpen Pada Peserta didik Kelas X.F SMAN 2 Playen Gunung Kidul Penggunaan model Jurisprudential Inquiry dapat meningkatkan keterampilan menulis cerpen peserta didik kelas X F SMA Negeri 2 Playen.

Berdasarkan paparan penjelasan di atas, peneliti memilih SMA Dua Mei sebagai objek penelitian untuk melihat pengaruh penggunaan model pembelajaran Jurisprudential Inquiry terhadap kemampuan berargumentasi peserta didik. Dengan menggunakan model pembelajaran Jurisprudential Inquiry dapat mengembangkan kemampuan berargumentasinya, me- milah informasi yang tepat dan memposisikan diri di masyarakat. Berdasarkan uraian-uraian tersebut diatas maka peneliti tertarik untuk mengadakan penelitian dengan judul "Pengaruh Model Pembelajaran Jurisprudential Inquiry Terhadap Kemampuan Berargumentasi Peserta Didik".

\section{LANDASAN TEORI}

\section{Hakikat Model Pembelajaran}

Joyce, Weil, dan Calhoun (2011) mendeskripsikan empat kategori model mengajar, yaitu kelompok model social, kelompok pengolahan informasi, kelompok model personal, dan kelompok model sistem perilaku. Tiap-tiap model tersebut diajarkan ke dalam beberapa tipe yang lebih terukur.

Berdasarkan uraian di atas, maka Jurisprudential Inquiry merupakan salah satu model pembelajaran yang termasuk ke dalam kelompok model social. Model pembelajaran yang dipelopori oleh Donal Oliver dan James P. Shaver ini didasarkan atas pemahaman masyarakat di mana setiap orang berbeda pandangan dan prioritas satu sama lain, dan nilai-nilai sosialnya saling berkonfrontasi satu sama lain. Memecahkan masalah kompleks dan kontroversial di dalam konteks aturan sosial yang produktif membutuhkan warga negara yang mampu berbicara satu sama lain dan bernegosiasi tentang keberbedaan tersebut.

Jadi, model pembelajaran telah yurisprudensial melatih peserta didik untuk peka terhadap permasalahan sosial, mengambil posisi (sikap) terhadap permasalahan tersebut, serta mempertahankan sikap tersebut dengan argumentasi yang relevan dan valid. Model ini juga dapat mengajarkan peserta didik untuk dapat menerima atau menghargai sikap orang lain terhadap suatu masalah yang mungkin bertentangan dengan sikap yang ada pada dirinya atau sebaliknya, menerima dan mengakui kebenaran sikap yang diambil orang lain terhadap suatu isu sosial tertentu.

\section{Kemampuan Argumentasi}

Penumbuhan Kemampuan menurut Wikipedia (2018) adalah kapasistas seorang individu untuk melakukan beragam tugas 
dalam suatu pekerjaan atau bisa dijelaskan bahwa kemampuan adalah sebuah penilaian terkini atas apa yang dapat dilakukan seseorang.

Argumentasi menurut Keraf (1981: 120) adalah suatu proses untuk mencapai suatu kesimpulan. Sedangkan dalam Kamus Bahasa Indoensia-Melayu (1997: 19) menyebutkan bahwa argumentasi adalah pemberian alasan dan penjelasan bukti-bukti yang disampaikannya sangat ilmiah. Dalam Kamus Besar Bahasa Indonesia berargumentasi adalah memberikan alasan untuk memperkuat atau menolak suatu pendapat. Dengan mempergunakan prinsipprinsip logika sebagai alat bantu utama, maka argumentasi atau tulisan argumentative yang ingin mengubah sikap dan pendapat orang lain bertolak dari dasar-dasar tertentu, menuju sasaran yang hendak dicapainya (Keraf, 1981: 85).

Jadi, dapat disimpulkan bahwa kemampuan berargumentasi adalah kemampuan untuk mencapai suatu kesimpulan dengan menggunakan dasar prinsip-prinsip logika. Dasar yang harus diperhatikan sebagai titik tolak argumentasi adalah: (1) pembicara atau pengarang harus mengetahui serba sedikit tentang subyek yang akan dikemukakannya, sekurang-kurangnya mengenai prinsip-prinsip ilmiahnya, pengarang harus bersedia mempertimbangkan pandangan-pandangan atau pendapat-pendapat yang bertentangan dengan pendapatnya sendiri, dan (3) pembicara atau penulis argumentasi harus berusaha untuk mengemukakan pokok persoalnnya dengan jelas.

Terdapat indikator-indikator dalam mengukur kemampuan berargumentasi peserta didik, di antaranya. Argumentasi menurut Mc. Neil dan Krajick (dalam Pritasari, 2016) memuat tiga aspek meliputi: (1) Claim merupakan pernyataan yang menjawab pertanyaan, (2) Evidence data ilmiah yang mendukung suatu pernyataan, dan (3) Reasoning merupakan suatu alasan atau pembenaran yang menguhubungkan pernyataan dengan bukti.

Menurut Toulmin dalam Budiyono (2016) terdapat empat indikator untuk mengukur kemampuan berargumentasi peserta didik, yaitu: (1) klaim mengukur kemampuan berargumentasi berupa pernyataan, (2) data disertakan untuk mendukung klaim, diukur berdasarkan aspek kecukupan dan kualitas data,

(3) pembenaran digunakan untuk menjelaskan hubungan antara data dan klaim, dan (4) dukungan digunakan untuk mendukung sebuah pembenaran.

Sedangkan menurut sumber lain, indikator kemampuan berargumentasi adalah:

1. Keaktifan dalam berdiskusi. Bahwa peserta didik dinilai mempunyai kemampuan berargumentasi jika ia mampu aktif dan terlibat dalam kegiatan belajar mengajar. Keaktifan tersebut dinilai dengan ia mampu menjawab pertanyaan-pertanyaan yang telah guru berikan, selain itu dia bisa menanyakan hal-hal atau materi yang tidak dapat dipahaminya.

2. Ketepatan dalam menunjukan data. Bahwa dalam berargumentasi, peserta didik harus mampu menunjukan ketepatan dari argumennya tersebut, berkaitan dengan isu-isu atau masalah yang sedang dibahas dalam kegiatan belajar mengajar di kelas.

3. Keaslian dalam referensi. Bahwa keaslian merupakan hal yang sangat penting dalam berargumen, peserta didik diharapkan mampu menyatakan argumennya sendiri dan dipastikan peserta didik tidak mengambil karya orang lain tanpa mengutip dan mencamtumkan sumberya dengan jelas.

4. Kelancaran dalam berargumen. Bahwa kelancaran dalam berargumentasi, dalam artian peserta didik tidak terbata-bata dalam menyampaikan argumennya.

\section{METODE PENELITIAN}

Penelitian ini menggunakan pendekatan kuantitatif dengan jenis Quasi Eksperimen. Desain quasi eksperimen yang digunakan adalah The Pretest-Posttest Control Group Design.

Tabel 1 The Pretest-Posttest Control Group Design

\begin{tabular}{|c|c|c|c|}
\hline \multicolumn{1}{|c|}{ Perlakuan } & Pretest & Perlakuan & Postest \\
\hline A- Eksperimen & O1 & X1 & O2 \\
\hline B- Kontrol & O3 & - & O4 \\
\hline
\end{tabular}

Keterangan:

A : Kelompok Eksperimen

B : Kelompok Kontrol,

$\mathrm{O} 1$ dan $\mathrm{O} 3$ : Pretest

$\mathrm{O} 2$ dan $\mathrm{O} 4$ : Posttest

X1 : Perlakuan dengan menerapkan Model Jurisprudential Inquiry 
Pemilihan desain ini untuk mengetahui perbedaan rata-rata skor kemampuan argumentasi antara kelompok eksperimen yang menggunakan Model Jurisprudential Inquiry dengan kelompok kontrol yang menggunakan model pembelajaran konvensional.

Berikut tabel 2, penjabaran indikator kemampuan argumentasi beserta kriteria skor penilaian.

Tabel 2 Penjabaran Indikator Kemampuan Argumentasi dan Kriteria Skor Penilaian

\begin{tabular}{|c|l|l|l|l|l|}
\hline \multirow{2}{*}{ No } & \multicolumn{2}{|c|}{ Kemampuan Argumentasi } & \multicolumn{3}{|c|}{ Skor dan Kriteria } \\
\cline { 2 - 6 } & \multicolumn{1}{|c|}{ Unsur } & \multicolumn{1}{c|}{ Aspek } & \multicolumn{1}{c|}{$\mathbf{2}$} & \multicolumn{1}{c|}{$\mathbf{3}$} \\
\hline 1 & Klaim & $\begin{array}{l}\text { Akurasi } \\
\text { klaim }\end{array}$ & $\begin{array}{l}\text { Klaim sepenuhnya } \\
\text { tidak akurat }\end{array}$ & $\begin{array}{l}\text { Klaim sebagian } \\
\text { akurat }\end{array}$ & $\begin{array}{l}\text { Klaim } \\
\text { Sepenuhnya akurat }\end{array}$ \\
\hline 2 & Data & $\begin{array}{l}\text { Kecukupan } \\
\text { data }\end{array}$ & $\begin{array}{l}\text { Menyertakan } \\
\text { data tetapi tidak } \\
\text { relevan untuk } \\
\text { mendukung }\end{array}$ & $\begin{array}{l}\text { Menyertakan data } \\
\text { tetapi tidak cukup } \\
\text { untuk mendukung } \\
\text { klaim }\end{array}$ & $\begin{array}{l}\text { Menyertakan } \\
\text { data yang } \\
\text { cukup untuk } \\
\text { mendukung klaim }\end{array}$ \\
\cline { 3 - 6 } & Kualitas data & $\begin{array}{l}\text { Data ada tetapi } \\
\text { tidak dianalisis } \\
\text { untuk mendukung } \\
\text { klaim }\end{array}$ & $\begin{array}{l}\text { Data sebagian } \\
\text { dianalisis untuk } \\
\text { mendukung klaim }\end{array}$ & $\begin{array}{l}\text { Data sepenuhnya } \\
\text { dianalisis untuk } \\
\text { mendukung klaim }\end{array}$ \\
\hline 3 & Pembenaran & $\begin{array}{l}\text { Kualitas } \\
\text { pembenaran }\end{array}$ & $\begin{array}{l}\text { Pembenaran untuk } \\
\text { menjelaskan } \\
\text { hubungan antara } \\
\text { data dan klaim tidak } \\
\text { mendukung klaim }\end{array}$ & $\begin{array}{l}\text { Pembenaran untuk } \\
\text { menjelaskan } \\
\text { hubungan antara } \\
\text { data dan klaim } \\
\text { sebagian } \\
\text { mendukung klaim }\end{array}$ & $\begin{array}{l}\text { Pembenaran untuk } \\
\text { menjelaskan } \\
\text { hubungan antara } \\
\text { data dan klaim } \\
\text { sepenuhnya } \\
\text { mendukung klaim }\end{array}$ \\
\hline 4 & Dukungan & $\begin{array}{l}\text { Kualitas } \\
\text { dukungan }\end{array}$ & $\begin{array}{l}\text { Dukungan untuk } \\
\text { melandasi } \\
\text { pembenaran tidak } \\
\text { mendukung klaim }\end{array}$ & $\begin{array}{l}\text { Dukungan untuk } \\
\text { melandasi } \\
\text { kembenaran } \\
\text { sebagian } \\
\text { mendukung klaim }\end{array}$ & $\begin{array}{l}\text { Dukungan untuk } \\
\text { menlandasi } \\
\text { pembenaran } \\
\text { sepenuhnya } \\
\text { mendukung klaim }\end{array}$ \\
\hline
\end{tabular}

Sumber: Adaptasi dari Toulmin dalam Budiyono (2016)

Analisis data dilakukan dengan membandingkan rata-rata skor kemampuan berargumentasi kelompok eksperimen dan kelompok kontrol dengan membandingkan nilai sebelum dan sesudah perlakuan dengan terlebih dahulu membuat tabel skor pretest dan posttest peserta didik kelas eksperimen dan kontrol, selanjutnya menghitung peningkatan skor yang terjadi sebelum dan sesudah penerapan model (gain). Selanjutnya melakukan uji normalitas, menguji homogenitas, pada data pretest, posttest dan gain. Setelah memnuhi syarat normal dan homogen, dilakukan uji rerata skor pretest dan uji perbedaan rerata setelah perlakuan dan uji Perbedaan Perolehan (gain) masing-masing kelompok (kelompok eksperimen dan kelompok kontrol).

\section{HASIL DAN PEMBAHASAN}

Penelitian ini membahas mengenai pengaruh model pembelajaran Jurisprudential Inquiry terhadap kemampuan berargumentasi peserta didik pada mata pelajaran ekonomi. Penelitian ini dilakukan di SMA Dua Mei Tangerang Selatan. Pengambilan teknik sampel pada penelitian ini menggunakan purposive sampling yaitu berdasarkan atas pertimbangan tertentu sesuai dengan keinginan peneliti. Pada pelaksanaanya peneliti mengambil dua kelompok sampel yang sudah ditentukan oleh guru kelas atas pertimbangan tertentu untuk dijadikan sampel. Jumlah sampel yang akan diteliti sebanyak 64 peserta didik di kelas X SMA Dua Mei, kelas X IPS 1 dijadikan sebagai kelas eksperimen dengan jumlah 32 peserta didik dan kelas X IPS 2 dijadikan sebagai kelas kontrol dengan jumlah 32 peserta didik. Kelas 
eksperimen mendapat perlakuan menggunakan model pembelajaran Jurisprudential Inquiry dan kelas kontrol menggunakan model pembelajaran konvensional berupa ceramah.

Rangkaian Pengujian dilalui dengan terlebih dahulu melakukan uji validitas untuk mengukur tingkat akurasi instrumen yang akan diberikan kepada sampel untuk diteliti. Uji validitas yang digunakan oleh peneliti yaitu soal tes kemampuan berargumentasi. Instrumen soal tes kemampuan berargumentasi dikonsultasikan oleh dosen ahli yang diposisikan sebagai judge expert. Soal tes kemampuan berargumentasi berbentuk essay yang berjumlah 7 soal. Setelah mendapatkan persetujuan mengenai kejelasan dan kevalidan instrumen dari dosen pembimbing, peneliti melalukan uji validitas di kelas XI IPS 1 dengan jumlah 32 siswa.

Dari hasil uji validitas soal tes kemampuan berargumentasi, soal dari nomor 1 sampai dengan nomor 7 dinyatakan valid karena $r$ hitung $\geq \mathrm{r}$ tabel. Dari tabel di atas dapat dianalisis, soal nomor 2 , memiliki nilai $r$ hitung yang lebih rendah dibandingkan dengan $r$ hitung yang diperoleh dari beberapa soal lainnya. Soal tes memecahkan masalah nomor dua yang ditanyakan yaitu tentang penyebab kelangkaan di Indonesia. Tingkat kesukaran soal tes kemampun berargumentasi untuk kelas XI IPS 1 terdapat di soal nomor 2. Meskipun soal nomor 2 memiliki nilai $r$ hitung lebih rendah dibandingkan nilai $r$ hitung yang diperoleh beberapa soal lain, soal nomor 2 dinyatakan valid. Soal tes kemampuan berargumentasi yang berjumlah 7 soal dinyatakan valid, setelah itu soal tes kemampuan berargumentasi diuji reliabilitasnya.

Uji reliabilitas yaitu uji untuk menentukan reliabilitasnya butir-butir soal yang akan djadikan pretest dan posttest. Uji reliabilitas dapat dilakukan, setelah butir-butir soal telah dilaku- kan uji validitas. Dalam penelitian menggunakan cronbach alpha untuk menentukan tingkat reliabilitas butir-butir soal tes kemampuan berargumentasi. Butir-butir soal tes kemampuan berargumentasi dikatakan realibel, apabila nilai alpha $\geq 0,600$. Hasil uji coba instrumen soal tes kemampuan berargumentasi kemudian dianalisis dengan bantuan software SPSS Version 21. Berikut Ini hasil uji reliabilitas soal tes kemampuan kemampuan berargumentasi di kelas XI IPS 1 SMA Dua Mei:

Tabel 3 Uji Reliabilitas Soal Tes Kemampuan Berargumentasi

\begin{tabular}{|c|c|c|c|}
\hline $\begin{array}{c}\text { Item } \\
\text { Pertanyaan }\end{array}$ & $\begin{array}{c}\text { cronbach } \\
\text { alpha }\end{array}$ & N of Item & Keterangan \\
\hline $\begin{array}{c}\text { Permasalahan } \\
\text { Ekonomi }\end{array}$ & 0,807 & 7 & Reliable \\
\hline
\end{tabular}

Sumber: Data primer penelitian 2018

Dari hasil uji reliabilitas yang terdapat pada tabel di atas, butir-butir soal tes memecahkan masalah dinyatakan reliable karena nilai cronbach alpha $\geq 0,600$. Nilai Cronbach Alpha dengan total 0,807 termasuk kategori yang tinggi untuk uji reliabilitas. Apabila soal tes kemampuan berargumentasi dinyatakan reliable, maka peneliti dapat menggunakan soal tes memecahkan masalah untuk pretest dan posttest yang akan diujikan di kelas X IPS 1 dan X IPS 2.

\section{UJI PRASYARAT ANALISIS DATA Statistik Deskriptif}

Statistik deskriptif adalah bagian dari statistik yang mempelajari cara pengumpulan dan penyajian data sehingga mudah dipahami. Statistik deskriptif hanya berhubungan dengan hal yang menguraikan atau memberikan keterangan-keterangan mengenai suatu data atau keadaan atau fenomena. 
Tabel 4 Statistik Deskripsi

\begin{tabular}{|l|r|r|r|r|}
\hline & $\begin{array}{c}\text { pretest } \\
\text { eksperimen }\end{array}$ & $\begin{array}{c}\text { postest } \\
\text { eksperimen }\end{array}$ & pretest kontrol & postest kontrol \\
\hline N & 32 & 32 & 32 & 32 \\
Mean & 0 & 0 & 0 & 0 \\
Median & 61.44 & 79.94 & 58.44 & 64.81 \\
Mode & 65.00 & 80.00 & 56.00 & 65.00 \\
Std. Deviation & 67 & 80 & 54 & 60 \\
Minimum & 8.048 & 6.133 & 6.565 & 5.202 \\
Maximum & 45 & 65 & 45 & 55 \\
Sum & 72 & 92 & 72 & 75 \\
& 1966 & 2558 & 1870 & 2074 \\
\hline
\end{tabular}

Sumber: Data primer penelitian 2018

Berdasarkan tabel 4, didapati nilai rata-rata pretest kelas ekperimen adalah 61.44 dan meningkat pada posttest sebesar 79.94, sedangkan nilai rata-rata pretest kelas kontrol adalah 58.44 dan posttest 64.81 . Modus pada masing-masing tes adalah 67 dan 80 untuk tes awal akhir kelas eksperimen, serta 54 dan 60 untuk tes awal dan akhir kelas kontrol. Dan median kelas eksperimen pada tes awal adalah 65 dan pada tes akhir adalah 80, sedangkan median pada kelas kontrol adalah 56 untuk tes awal dan 65 untuk tes akhir.

\section{Uji Normalitas}

Uji normalitas digunakan untuk mengetahui data penelitian berdistribusi normal atau tidak. Data yang akan diuji normalitas yaitu data pretest kerjasama siswa dan data pretest tes memecahkan masalah. Penelitian ini menggunakan uji normalitas Kolmogorof-Sminov. Berdasakan uji normalitas Kolmogorof-Sminov, data dinyatakan berdistribusi normal apabila nilai sig $>0,05$. Jika nilai sig $<0,05$ maka data dinyatakan tidak berdistribusi normal. Hasil perhitungan uji normalitas Kolmogorov-Smirnov diperoleh dengan bantuan software SPSS Version 20.

\section{Uji Normalitas Data Pretest Kemampuan Berargumentasi}

Uji normalitas data pretest dilakukan untuk mengetahui data pretest kemampuan ber- argumentasi yang ada di kelas kontrol dan kelas eksperimen berdistribusi normal atau tidak. Pengambilan data pretest kerjasama kelas kontrol dilakukan di kelas X IPS 2 dengan menggunakan model pembelajaran konvensional yaitu diskusi dan pengambilan data pretest kerjasama kelas eksperimen dilakukan di kelas $\mathrm{X}$ IPS 1 dengan menggunakan model pembelajaran Jurisprudential Inquiry. Berikut ini hasil uji normalitas data pretest kerjasama di kelas eksperimen dan kelas kontrol

Tabel 5 Uji Normalitas Data Pretest Kemampuan Berargumentasi Siswa Kelas Kontrol dan Eksperimen One-Sample Kolmogorov-Sminov'Test

\begin{tabular}{|ll|r|}
\hline & & $\begin{array}{r}\text { Unstandardized } \\
\text { Residual }\end{array}$ \\
\hline $\mathrm{N}$ & Mean & 64 \\
Normal Parameters & Std. & \\
& Deviation & 7.28528632 \\
& Absolute & .166 \\
Most Extreme & Positive & .166 \\
Differences & Negative & -.152 \\
& & 1.330 \\
Kolmogorov-Smirnov Z & .058 \\
Asymp. Sig. (2-tailed) & & \\
\hline
\end{tabular}

Sumber: Data Primer Penelitian 2018 
Berdasarkan tabel 5 di atas menunjukkan hasil pengujian normalitas dengan menggunakan Kolmogorov-Smirnov data pretest kerjasama siswa dinyatakan berdistribusi normal karena nilai taraf signifikasi (Sig) yang diperoleh dari kelas eksperimen dengan uji normalitas Kolmogorov-Smirnov lebih besar dari 0.05. Hasil yang diperoleh uji normalitas normalitas Kolmogorov-Smirnov di kelas eksperimen yaitu bernilai 0,058 >0,05.

Uji normalitas Kolmogorov-Smirnov di kelas kontrol dinyatakan berdistribusi normal karena nilai taraf signifikasi (Sig) yang di peroleh lebih besar dari 0,05 . Hasil yang diperoleh uji normalitas data pretest kemampuan berargumentasi siswa dengan menggunakan Kolmogorov-Smirnov di kelas kontrol yaitu bernilai 0,058 > 0,05.

\section{Uji Homogenitas}

Uji homogenitas digunakan untuk mengetahui data penelitian mempunyai data yang homogen atau tidak. Data yang akan diuji homogenitas yaitu data pretest kemampuan berargumentasi peserta didik dan data pretest homogenitas yaitu data pretest tes kemampuan berargumentasi. Penelitian ini menggunakan uji homogenitas Levene. Berdasarkan uji homogenitas dengan Levene, data dinyatakan homogeny apabila nilai Sig $>0,05$. Jika Sig $<0,05$ maka data dinyatakan tidak homogeny. Hasil perhitungan uji homogenitas, Levene, diperoleh dengan bantuan software SPSS version 20 .

\section{Uji Homogenitas Data Pretest Kemampuan Berargumentasi}

Uji homogenitas data pretest kemampuan berargumentasi peserta didik dilakukan untuk mengetahui pretest kemampuan berargumentasi yang ada di kelas kontrol dan kelas eksperimen mempunyai data yang homogeny atau tidak. Pengambilan data pretest kemampuan berargumentasi peserta didik kelas eksperimen dilakukan di X IPS 1 dengan menggunakan model Jurisprudential Inquiry dan pengambilan data pretest pada kelas kontrol di kelas X IPS 2 dengan menggunakan model konvensional yaitu diskusi. Berikut ini hasil uji homogenitas data pretest kemampuan berargumentasi di kelas eksperimen dan kelas kontrol.

\section{Tabel 6 Uji Homogenitas Data Pretest Kemampuan Berargumentasi Siswa Kelas Kontrol dan Eksperimen Test of Homogeneity of Variances}

\begin{tabular}{|c|c|c|c|}
\hline Levene Statistic & df1 & df2 & Sig. \\
\hline 3.058 & 1 & 62 & .085 \\
\hline
\end{tabular}

Sumber: Data Primer Penelitian 2018

Berdasarkan tabel di atas menunjukkan hasil pengujian homogenitas dengan menggunakan levene, data pretest kemampuan berargumentasi peserta didik dinyatakan homogen karena nilai taraf signifikansi (Sig) yang diperoleh dari kelas eksperimen dan kelas kontrol lebih besar dari 0,005. Hasil yang diperoleh uji homogenitas dengan menggunakan levene statistic bernilai 3.058 dengan signifikansi $0.085>0.05$. dapat disimpulkan data pretest kemampuan berargumentasi peserta didik di kelas kontrol dan kelas eksperimen mempunyai data yang homogen.

\section{UJI HIPOTESIS}

\section{Uji Independent Sampel T-Test}

Hasil uji prasyarat analisis data menunjukkan data pretest kemampuan berargumentasi mempunyai data yang homogeny dan berdistribusi normal. Tahap selanjutnya dilakukan uji hipotesis dnegan uji T-Test Independen Sampel Test untuk mengetahui seberapa besar tingkat pengaruh model pembelajaran Jurisprudential Inquiry terhadap kemampuan berargumentasi pada mata pelajaran ekonomi. Kriteria pengujian hipotesis T-test Independen Sampel Test yaitu apabila nilai taraf signifikansi $(\mathrm{Sig})<0,05$ maka terdapat pengaruh model pembelajaran Jurisprudential Inquiry terhadap kemampuan berargumentasi peserta didik.

\section{Hipotesis}

$\begin{aligned} \mathrm{Ho}= & \text { Model Pembelajaran Jurisprudential } \\ & \text { Inquiry tidak berpengaruh terhadap } \\ & \text { kemampuan berargumentasi peserta } \\ & \text { didik. } \\ \mathrm{Ha}= & \text { Model Pembelajaran Jurisprudential } \\ & \text { Inquiry berpengaruh positif dan } \\ & \text { signifikansi terhadap kemampuan } \\ & \text { berargumentasi peserta didik }\end{aligned}$




\section{Kriteria Pengambilan Keputusan}

Maka dengan tingkat kepercayaan $=95 \%$ atau $(\alpha)=0,005$. Derajat kebebasan $(\mathrm{df})=\mathrm{n}-\mathrm{k}-$ $1=32-1-1=30$, serta pengujian dua sisi diperoleh dari nilai t $0,05=1,6972$. Ho diterima apabila ttabel $\leq$ thitung $\leq$ ttabel atau Sig $\geq 5 \%$. Sedangkan Ho ditolak apabila thitung $<$ ttabel atau $\operatorname{Sig}<5 \%$.

Tabel 7 Uji -t Data Posttest Kemampuan Berargumentasi Siswa Kelas Kontrol dan Eksperimen Independent Samples Test

\begin{tabular}{|cc|c|c|c|c|c|}
\hline \multirow{2}{*}{} & \multicolumn{2}{|c|}{$\begin{array}{c}\text { Levene's Test for } \\
\text { Equality of } \\
\text { Variances }\end{array}$} & \multicolumn{3}{|l|}{ t-test for Equality of Means } \\
\cline { 3 - 7 } & F & Sig. & T & Df & $\begin{array}{c}\text { Sig. } \\
(2- \\
\text { tailed }\end{array}$ \\
\hline $\begin{array}{c}\text { nilai } \\
\text { ekonomi }\end{array}$ & Equal variances assumed & .400 & .529 & 10.639 & 62 & .000 \\
.000 \\
\hline
\end{tabular}

Sumber: Data Primer Penelitian, diolah pada tanggal 13 Oktober 2018

Berdasarkan tabel 6 menunjukkan pengujian hipotesis dengan Uji Independen Sampel T-Test diperoleh nilai t sebesar 10.639 dengan nilai taraf signifikansi (Sig) sebesar $0,000<0,005$ yang berarti memenuhi kriteria pengujian yaitu $((\operatorname{Sig}(2$-tailed $))<0,005$ yaitu $0,000{ }^{\circ}<0,05$ maka Ho ditolak dan H1 diterima. Dapat ditarik kesimpulan bahwa terdapat pengaruh model Jurisprudential Inquiry terhadap kemampuan berargumentasi peserta didik.

\section{HASIL DAN PEMBAHASAN}

\section{Pengaruh Model Jurisprudential Inquiry terhadap Kemampuan Berargumentasi Peserta Didik}

Berdasarkan hasil penelitian, menunjukkan bahwa model pembelajaran Jurisprudential Inquiry berpengaruh positif dan signifikan terhadap kemampuan berargumentasi. Hal ini dibuktikan dnegan hasil uji statistik, uji-t, diperoleh nilai $\mathrm{t}$ hitung sebesar 10,639 dan $\mathrm{t}$ tabel 1,697 dengan nilai taraf signifikansi (Sig) sebesar 0,000, karena thitung $>$ ttabel $(10,639>1,697)$, signifikansi lebih kecil dari $0,05(0,000<0,05)$, maka penelitian ini berhasil membuktikan hipotesis yang menyatakan
"Model Pembelajaran Jurisprudential Inquiry berpengaruh terhadap Kemampuan Berargumentasi Peserta Didik".

Proses pembelajaran ekonomi di kelas kontrol dan kelas eksperimen dilaksanakan selama empat kali pertemuan. Materi yang diajarkan yaitu tentang kebutuhan manusia. Teknik pengumpulan data digunakan oleh peneliti yaitu tes kemampuan berargumen yang terdiri dari 7 soal yang berbentuk essay. Model pembelajaran Jurisprudential Inquiry yang diterapkan di kelas eksperimen berhasil meningkatkan kemampuan berargumentasi peserta didik dengan nilai awal rata-rata 61,44 meningkat menjadi 79,94. Sedangkan pada kelas kontrol yang tidak diterapkan model Jurisprudential Inquiry rata-rata awal sebesar 58,44 dan hanya meningkat sebsar 64,81. Peningkatan prosentasi hasil tes pada kelas eksperimen sebesar $23,14 \%$ sedangkan pada kelas kontrol berdasarkan hasil tes awal dan akhir hanya meningkat sebesar 9,82\%. Hal ini membuktikan bahwa dengan menerapkan model pembelajaran Jurisprudential Inquiry maka kemampuan berargumentasi lebih meningkat daripada dengan menggunakan model pembelajaran konvensional. 
Hal ini sejalan dengan teori model pembelajaran menurut Joyce, Weil dan Calhoun (2011) bahwa dengan menggunakan model guru dapat membantu peserta didik untuk mendapatkan atau memperoleh informasi, ide, keterampilan, cara berpikir, dan mengekspresikan ide diri sendiri.

Dengan menggunakan model pembelajaran yang inovatif maka kegiatan belajar mengajar tidak lagi berpusat pada peserta didik, hal itu akan memunculkan ide-ide atau pendapat-pendapat peserta didik.

Menurut Soekamto dalam (Kasmad, 2012: hal. 59) tujuan menggunakan model pembelajaran adalah untuk menciptakan suasana yang menunjang agar peserta didik merasa bebas untuk merespon secara alami dan teratur. Dengan meningkatkan nilai mata pelajaran ekonomi peserta didik dengan menggunakan model pembelajaran maka bisa dipastikan tujuan belajar tercapai dengan baik. Model pembelajaran berfungsi pedoman bagi pengajar dalam merencanakan aktivitas belajar mengajar. Maka dari itu, seorang pengajar memerlukan model-model pembelajaran yang inovatif berdasarkan kebutuhan peserta didik karena masing-masing model pembelajaran memiliki tujuan, prinsip, dan tekanan yang berbeda.

Model Pembelajaran Jurisprudential Inquiry oleh Donal Oliver dan James P. Shaver ini melatih peserta didik untuk peka terhadap permasalahan sosial, mengambil posisi (sikap) terhadap suatu permasalahan, serta mempertahankan sikap dengan argumentasi yang relevan dan valid. Secara umum tahap pembelajaran model Jurisprudential Inquiry yaitu pertama, orientasi kasus dimana pada tahap ini guru mengajukan kasus yang sedang hangat di masyarakat atau kasus di sekolah. Dimana pada penelitian ini guru memberikan kasus berbagai sumber ekonomi yang langka dan kebutuhan manusia yang tidak terbatas kemudian peserta didik meninjau fakta-fakta dengan melakukan analisis. Langkah kedua adalah identifikasi isu, pada tahap ini peserta didik dibimbing untuk mensintesis fakta-fakta yang ada ke dalam sebuah isu yang sedang dibahas, pada tahap ini peserta didik belum diminta untuk menentukan pendapatnya terhadap kasus yang sedang dibahas. Langkah selanjutnya yaitu peserta didik menyatakan posisinya, peserta didik mengambil posisi pro atau kontra terhadap permasalahan yang sedang dibahas oleh peneliti. Langkah selanjutnya adalah menyelidiki cara berpendirian dan pola argumentasi, pada tahap ini peserta didik memberikan data-data dan bukti-bukti sebagai bahan pendukung argumentasinya, kemudian mengevaluasi kekurangan-kekurangan daru nilai atau keputusan yang lainnya. Langkah kelima yaitu memperbaiki dan mengkualifikasi posisi dimana pada tahap ini peserta didik mempetimbangkan posisinya apakah dia akan bertahan pada posisinya atau akan berpindah dengan cara menguji sejumlah situasi atau kondisi yang mirip terhadap permasalahannya, langkah terakhir adalah melakukan pengujian asumsi-asumsi terhadap posisinya atau pendapatnya.

Kelebihan dari model ini merupakan model yang dianggap sesuai dengan perkembangan psikologi belajar modern yang menganggap belajar adalah proses perubahan tingkah laku dibuktikan denga adanya tanggapan posisi peserta didik yang kemudian bisa berpindah posisi jika merasa tidak benar permasalahannya. Sedangkan kekurangannya adalah dalam mengimplementasikannya, memerlukan waktu yang panjang sehingga sering guru sulit menyesuaikannya dengan waktu yang telah ditentukan.

Model Jurisprudential Inquiry adalah model yang melatih peserta didik untuk bisa berargumen, argumentasi adalah pemberian alasan dan penjelasan bukti-bukti yang yang disampaikannya ilmiah. Argumentasi adalah memberikan alasan untuk memperkuat atau menolak suatu pendapat (KBBI, 2008: hal. 85). Indikator yang dipakai peneliti adalah dari Toulmin yang terdapat empat indikator yaitu klaim, untuk mengukur kemampuan berargumentasi berupa pernyataan. Kemudian data, disertakan untuk mendukung klaim diukur berdasarkan aspek kecukupan dan kualitas data, yaitu pembenaran digunakan untuk menjelaskan hubungan antara data dan kalim serta dukungan yang digunakan untuk mendukung sebuah pembenaran (Budiyono, 2016).

Hasil penelitian ini konsisten dengan hasil penelitian yang dilakukan oleh Tiyani (2013) yang menyatakan bahwa model pembelajaran 
Jurisprudential Inquiry dapat meningkatkan keterampilan menulis cerpen peserta didik dengan nilai rata-rata kemampuan menulis cerpen meningkat sebesat 6,27\%. Sejalan dengan hal tersebut, Sanjaya menjelaskan bahwa kelebihan dari model Jurisprudential Inquiry adalah model pembelajaran yang menekankan kepada pengembangan aspek kognitif, afektif, dan psikomotorik, secara seimbang sehingga pembelajaran akan lebih bermakna. Model pembelajaran Jurisprudential Inquiry juga dapat mengajarkan peserta didik untuk dapat menerima atau menghargai sikap orang lain terhadap suatu masalah yang mungkin bertentangan dengan sikap yang ada pada dirinya, atau sebaliknya, ia bahkan menerima dan mengakui kebenaran sikap yang diambil orang lain terhadap suatu isu sosial tertentu. Model pembelajaran Jurisprudential Inquiry melatih peserta didik untuk peka terhadap permasalahan tersebut, serta dapat mengembangkan kemampuan berargumentasi dengan isu-isu yang diberikan oleh guru. dengan menggunakan model pembelajaran Jurisprudential Inquiry setiap peserta didik mempunyai kesempatan untuk berargumentasi sesuai dengan posisinya atau sikapnya.

\section{KESIMPULAN}

Berdasarkan hasil penelitian dan pembahasan analisis data, maka dapat disimpulkan bahwa terdapat pengaruh model pembelajaran Jurisprudential Inquiry terhadap kemampuan berargumentasi peserta didik. Hal ini dibuktikan dengan perolehan nilai uji T-Test Independen Sampel Test diperoleh nilai $\mathrm{t}$ sebesar 10.639 dengan nilai taraf signifikansi (Sig) sebesar $0,000<0,005$ yang berarti memenuhi kriteria pengujian yaitu ((Sig (2-tailed) $)<0,005$ yaitu $0,000<0,05$ maka Ho ditolak dan H1 diterima. Terdapat peningkatan rata-rata nilai kemampuan berargumentasi di kelas eksperimen dari nilai rata-rata pretest 61,44 meningkat dari nilai post-test kemampuan kerjasama menjadi 79,94. Sehingga model pembelajaran Jurisprudential Inquiry berpengaruh terhadap kemampuan berargumentasi peserta didik pada mata pelajaran ekonomi di kelas IPS 1 di sekolah SMA Dua Mei Tangerang Selatan.

\section{DAFTAR PUSTAKA}

Aunurahman. (2010). Belajar dan Pembelajaran. Alfabeta: Bandung.

Budiyono, A. (2016). Pengaruh Penerapan Model Pembelajaran Argument Based Science Inquiry (ABSI) Terhadap Peningkatan Kemampuan Berargumentasi Siswa SMA. Universitas Islam Madura. Volume 4, Nomor 1.

Departemen Pendidikan dan Kebudayaan, Kamus Bahasa Indonesia-Melayu. (1997).

Departemen Pendidikan Nasional, Kamus Besar Bahasa Indonesia Edisi 4 Cet. 1. (2008). Jakarta: PT Gramedia Utama.

Hendrikus, D. W, (1991). Retorika Terampil Berpidato, Berdiskusi, Beragumentasi, Bernegosiasi. Yogyakarta: Kanisius.

Id.m.wikipedia.org. (8 Juli 2018).

Joyce, Marsha Weil dan Emily Calhoun. (2011). Model Of Teaching, Edisi 8. Yogyakarta: Pustaka Pelajar.

Kasmad, Mamad, dan Suko Pratomo. (2012). Modelmodel Pembelajaran Berbasis PAIKEM. Tangerang: Pustaka Mandiri.

Keraf, Gorys. (1981). Argumentasi dan Narasi. Jakarta: Gramedia Pustaka Utama.

Pritasari, A. Cyntia, dkk. (2016). Peningkatan Kemampuan Argumentasi Melalui Penerapan Model Problem Based Learning Pada Siswa Kelas X SMA Batik Surakarta Tahun Pelajaran 2014/2015. Universtas Negeri Surakarta. Volume 8, Nomor 1 .

Riyanti, Y. T. (2016). Model Pembelajaran Inkuiri Jurisprudensi Untuk Mengukur Hasil Belajar Peserta didik Sekolah Dasar Pada Pembelajaran PKn. Jurnal Pendidikan, Vol.4 No.1.

Rusman. (2012). Model-model Pembelajaran. Jakarta: Rajawali.

Tiyani, I. (2013). Pemanfaatan Model Jurisprudential Inquiry Untuk Meningkatkan Keterampilan Menulis Cerpen Pada Siswa Kelas X F SMA Negeri 2 Playen Gunungkidul. Yogyakarta: Skripsi Fakultas Bahasa dan Seni Universitas Negeri Yogyakarta.

Uno, H. B. (2014). Model Pembelajaran (Menciptakan Proses Belajar Mengajar yang Kreatif dan Efektif). Jakarta: Bumi Aksara. 